\title{
Freemartinism: Three Cases in Goats
}

\author{
I. SZATKOWSKA ${ }^{1}$, S. ZYCH1, J. UDAŁA ${ }^{2}$,A. DYBUS ${ }^{1}$, P. BŁASZCZYK ${ }^{1}$, P. SYSA ${ }^{3}$, \\ T. DĄBROWSKI ${ }^{3}$ \\ ${ }^{1}$ Department of Ruminant Science, Department of Animal Reproduction ${ }^{2}$, \\ Agricultural University of Szczecin, Poland \\ Department of Morphological Science, Warsaw Agricultural University, Warsaw, Poland \\ Received February 4, 2004 \\ Accepted July 29, 2004
}

Abstract

Szatkowska I., Zych S., Udała J., Dybus A., Błaszczyk P., P. Sysa, Dąbrowski T: Freemartinism: Three Cases in Goats. Acta Vet Brno 2004, 73: 375-378.

The aim of the study was a molecular and cytogenetic analysis of three cases of caprine freemartinism. The objects of the study were three White Improved goats culled due to infertility. The SRY gene was treated as a marker of presence (or absence) of the Y chromosome in the population of the blood nuclear cells carrying XY heterochromosomes, which occurs in a female organism originating from a heterosexual twin birth. In order to confirm cellular chimaerism that had been diagnosed basing on the presence of $S R Y$ gene, additional chromosomal analyses were carried out. Our studies have revealed that all three animals had the SRY gene linked with the Y chromosome. Bearing in mind that goats are genetically predestined to twin births, as well as due to a small incidence of clinically or molecularly diagnosed cases of freemartinism, it seems important to carry on studies in this scope, which can create a basis for wider characterisation of this syndrome in the domestic goat.

Infertility, freemartinism, goats

Freemartinism is a condition occurring in twins of different sexes, where an imperfect masculinised sterile female twin is born with a male. The syndrome has been mostly reported for cattle and sheep (Cole et al. 1997; Cribiu and Chaffaux 1990). Placental anastomoses that occur in the early embryonic life are responsible for freemartinism; their presence in females results in masculinisation (Mellor 1969). Clinical symptoms of this syndrome are accompanied by cell chimaerism (of erythrocytes and lymphocytes), expressed by an occurrence of two genetically differring cell lines which is used in diagnosis of freemartinism (Zhang et al. 1994; Justi et al. 1995; Ennis et al. 1999).

The incidence of freemartinism in goats has not been precisely established; however, an opinion is that the disorder is rather of marginal importance for the species. This may probably result from the fact that the main form of hermaphroditism in goats is represented by that linked with polledness. This opinion is, however, questionable, since results of studies on goats culled due to infertility have demonstrated that cell chimaerism in such animals occurred with a frequency of $4.85 \%$ (S zatkow ska et al. 2002). So far, only a few cases of freemartinism-affected goats have been reported (Yadav et al. 1993), hence presentation of three other cases of goats showing masculinisation changes, which was considered important from a cognitive standpoint.

\section{Materials and Methods}

Molecular studies were done on three infertile White Improved goats at age 1 to 4 years culled from a breeding stock of a herd managed in West Pomerania. The animals had been fed and housed in standard conditions. Blood was collected from external jugular vein into tubes containing EDTA. DNA isolation was carried out using Epicentre kits. PCR-multiplex (Mullis 1990) was performed in $25 \mu \mathrm{l}$ of mixture containing 15 pmol of each 
primer, $2 \mu \mathrm{l} 10 \times$ PCR buffer, $2.0 \mathrm{mM} \mathrm{MgCl2}, 200 \mu \mathrm{M}$ dNTP, 1 unit of Taq polymerase, and 100-150 ng of DNA. Primer sequences for two genes that were used for cell chimaerism identification were as follows: $S R Y \mathrm{~F}$ : 5'- CTCGTGAACGAAGACGAAAGG-3', SRY R: 5'-GCCTTC CGACGAGGTCGATACTTA-3' (Just et al. 1995) and GH F: 5'-CCCACGGGCAAGA ATGAGGC-3', GH F: 5'-TGAGGAACTGCAGGGGCCCA-3' (Mitra et al. 1995). The $S R Y$ gene was treated as a marker for presence (or absence) of the Y chromosome in the population of blood nuclear cells carrying XY heterochromosomes in the female organisms that originated from heterosexual twin births. In order to avoid an error resulting from other reasons than lack of DNA matrix, a region of the autosomal gene of growth hormone was simultaneously amplified with use of primers developed for domestic cattle; the GH gene constituted the positive control for each test. The PCR thermal profile in the form of 30 cycles was as follows: initial denaturation at $94{ }^{\circ} \mathrm{C}$ for $5 \mathrm{~min}$; further cycles: denaturation at $94{ }^{\circ} \mathrm{C}$ for $40 \mathrm{~s}$, primer annealing at $58^{\circ} \mathrm{C}$ for $60 \mathrm{~s}$, extension at $72^{\circ} \mathrm{C}$ for $60 \mathrm{~s}$; final extension at $72{ }^{\circ} \mathrm{C}$ for $10 \mathrm{~min}$. The PCR products were analysed in $2 \%$ agarose gel with $1 \mathrm{x}$ TBE and $1.0 \mu \mathrm{M}$ ethidium bromide. In order to confirm cell chimaerism that had been diagnosed basing on the presence of $S R Y$ gene PCR product, additional cytogenetic analyses were carried out, according methods developed for T-lymphocytes by Arakaki and Sparkes (1963). The chromosomal preparations were conventionally stained with $10 \%$ Giemsa solution. Metaphase spread examination was performed on microscopic images (magnified $\times 1500$ ) using the karyotype standard for Capra hircus L. (ISCNDA).

Detailed reproductive system examination was carried out after slaughter of two of the females (the third one had died before the experiment was completed).

\section{Results}

The molecular analysis demonstrated that all three animals under examination had both the region of autosomal GH gene and the SRY linked with the Y chromosome. Fig. 1 (see Plate V) presents the electrophoretic separation image.

The results of cytogenetic examinations confirmed that the studied goats had been inflicted with cell chimaerism, which is defined as 60,XX/60,XY. The studies were aimed not only to identify this chromosomal abnormality (i.e. to exclude translocation of Y chromosome with a SRY copy onto one of the autosomes or X chromosomes), but also to quantitatively estimate the percentage of cells with XY chromosomes that had originated from the male co-twin organisms (Table 1).

Table 1

Cellular lines within multiple births connected by anastomoses in the fetal life

\begin{tabular}{|l|c|cc|}
\hline Goat No & Number of metaphase plater & \multicolumn{2}{|c|}{ Number of Wells } \\
& & $60, \mathrm{XX}$ & $60, \mathrm{XY}$ \\
\hline $7-2 \mathrm{r}-\mathrm{F}$ & 100 & 32 & 68 \\
\hline $8-\mathrm{B}-97$ & 100 & 17 & 83 \\
\hline $18-\mathrm{N}-98$ & 100 & 44 & 56 \\
\hline
\end{tabular}

Clinical examination of the first goat (identified as 7-2r-F), which, although infertile, had remained in the herd for two reproduction seasons, revealed a normal female phenotype, i.e. with normally developed labia and clitoris. Besides a hypoplastic vagina $(2 \mathrm{~cm} \mathrm{long})$ with the urethra outlet in it, no other structures were found that could have been identified as gamete transporting organs, and no gonads were found as well (Plate V, Figs 2, 3).

The other of the studied goats (8-B-97) had remained in the herd for three reproduction seasons, however its phenotypic traits may have indicated possible developmental malformations of reproductive organs. This was expressed by an enlarged clitoris (Plate VI, Figs 4,5$)$. The post-mortem examination revealed equal-length ducts connected with the uterine horns, however inflammatory state of the entire reproductive organ prevented histological identification of these structures. No gonads were detected due to a huge cyst $(30 \mathrm{~cm} \times 28 \mathrm{~cm})$ with two ducts exiting it, of which one resembled a spermatic cord (funiculus spermaticus), as indicated by a network of blood vessels that are characteristic for this organ, whereas the other was connected with the uterus horns. 


\section{Discussion}

Previous studies on freemartinism in livestock animals, especially in ruminants, which due to their cotyledonary anatomy of placenta are those most commonly affected by this developmental disorder, have dealt primarily with cattle and sheep (Khan and Foley 1994; Satoh et al. 1997; S mith et al. 2002). In goats, as it was mentioned earlier, very few cases of freemartinism have been described in detail (Yadav et al. 1993); an analogy with cattle and sheep exists, however, in external reproductive organs which, except for enlarged clitoris, most often remain unchanged. Clinical changes in internal parts of a freemartin's reproductive system may be very diverse in form, since their development depends primarily on the sex-specific character of the gonads (Khan and Foley 1994; Vigier et al. 1991; S mith et al. 2003). Although secretory activity of freemartin foetal gonads has not been proved either in cattle or in sheep, a positive correlation exists between the stage of gonadal masculinisation and the sex-specific differentiation of gamete conducting organs (Chaffaux et al. 1987). Therefore, the moment when interfoetal circulation is initiated in the development of heterosexual twin births is very important, because the male co-twin's inhibitory effect on the shape of the female co-twin reproductive system may be due to the factors responsible for sex determination and differentiation (AMH, testosterone, dihydrotestosterone) (Vigier et al. 1991; R ot a et al. 2002). Should the specific twin-twin foetal circulation appear in the early stages of female reproductive system formation, the influence of male factors would be considerable (Szatkowska et al. 1998). This has been confirmed in the clinical studies on goats afflicted with cell chimaerism carried out by Yadaw et al. (1993), who found pseudotestes, located at the external inguinal ring, or other difficult to identify gonadal structures, which on histological examination turned out to be testes with well-developed seminiferous tubules. The characteristic female phenotype, though with an enlarged clitoris, represented a common feature of all reported cases. Similar cases have been described for cattle and sheep, although reproductive organs of the latter group showed a high degree of masculinisation with relatively well-developed testicles. However, if anastomoses occur during the later period of ontogenetic development, the inhibitory effect of the male co-twin will be diminished by secretion of androgens, as well as by the Wolffian duct tissue response to the activity of these steroids (Vigier et al. 1991), which prevents formation of male gamete transporting ducts. In consequence, those females may be afflicted with cell chimaerism, and yet have a normal structure of their reproductive system and, consequently, normally formed external reproductive organs, which has been described primarily in sheep (S zatk ow ska et al. 1993).The external genitalia of the cellchimaerism affected goats described in the presented study may be considered typical against the picture of freemartinism defined for other species of livestock animals; discussing masculinisation of internal reproductive organs poses some difficulty though. The totally absent reproductive system, except for the hypoplastic vagina, in one of the examined individuals is difficult to explain due to the fact that no similar case has been reported in the context of freemartinism. However, the lack of any structures, even in an aplastic form, which could be recognised as hypoplastic genitals or gonads without a certain sex specificity, is worth considering. The other of the analysed cases may be considered as more clear, however the acute inflammation of the genitals that had been caused by the large cyst did not allow proper identification of the gonads. Bearing in mind that goats are genetically predestined to twin births as well as due to a small incidence of clinically or molecularly diagnosed cases of freemartinism, it seems important to carry on studies in this scope, which could create grounds for wider characterisation of this syndrome in the domestic goat. 


\section{Tř̌i př́ípady freemartinismu u koz}

Cílem studie byla molekulární a cytogenetická analýza tří případů freemartinismu u koz. Zvířata plemene bílého ušlechtilého byla vyřazena $\mathrm{z}$ chovu pro infertilitu. Gen $\operatorname{SRY}$ byl použit jako marker přítomnosti či absence chromozomu Y v populaci buněk krevního nátěru nesoucích heterochromozomy XY. Tato situace bývá u samičích zvírat z heterosexuálních dvojčat. $\mathrm{K}$ potvrzení celulárního chimérismu diagnostikovaného na základě přítomnosti genu $S R Y$ jsme provedli další analýzy chromozomů. Naše studie ukázala, že všechna tři zvířata měla gen $S R Y$ spojený s chromozomem Y. Kozy jsou $\mathrm{k}$ porodům dvojčat geneticky predestinovány. Protože studie klinicky nebo molekulárně diagnostikovaných případů př́ípadů freemartinismu je zatím málo, je důležité takovéto studie provádět, aby bylo možné vytvořit širší charakteristiku tohoto syndromu u domácích koz.

\section{Acknowledgements}

The project was in part financed by the State Committee for Scientific Research grant No. 6 P06D 00321.

\section{References}

ARAKAKI, DT, SPARKES, RS 1963: Microtechnique for culturing leucocytes from whole blood. Cytogenetics 2: 57-60 CHAFFAUX, ST, MATEJKA, M, CRIBIU, EP, CRESPEAU, F, EYCHENNE, F, RICORDEAU, G 1987: Etude cytogenetique, anatomique et histologique de deux brebis romanov freemartins. Rec Med Vet 163: 15-21

COLE, J, BROADWELL, M, ROGERS, G 1997: Intersexuality in a Charolais heifer. Vet Rec 141(25): 656-7

CRIBIU EP, CHAFFAUX S 1990: Intersexuality in domestic mammals. Reprod Nutr Develop Suppl 1: 51-61

ENNIS, S, VAUGHAN, L, GALLAGHER, TF 1999: The diagnosis of freemartinism in cattle using sex-specific DNA sequences. Res Vet Sci 67(1): 111-2

ISCNDA, 1990: International System for Cytogenetic Nomenclature of Domestic Animals (1989). Cytogenet Cell Genet 53: $65-79$

JUST, W, RAU, W, VOGEL, W, AKHVERDIAN, M, FREDGA, K, GRAVES, JAM, LYAPUNOVA, E 1995: Absence of SRY in species of the vole Ellobius. Nat Genet 11: 117-118.

JUSTI, A, HECHT, W, HERZOG, A, SPECK, J 1995: Comparison of different methods for the diagnosis of freemartinism-blood group serology, cytology and polymerase chain reaction. Deut Tierarztl Woch 102: 471-4

KHAN, MZ, FOLEY, GL 1994: Retrospective studies on the measurements, karyotyping and pathology of reproductive organs of bovine freemartins. J Comp Pathol 110: 25-36

MELLOR, DJ 1969: Vascular anastomosis and fusion of foetal membranes in multiple pregnancy in sheep. Rec Vet Sci 10: 361-367

MITRA, A, SCHLEE, P, BALAKRISHNAN, CR, PIRCHNER, F 1995: Polymorphism at growth-hormone and prolactin loci in Indian cattle and bufflo. J Anim Breed Genet 112: 71-74

MULLIS, KB 1990: The unusual origin of the polymerase chain rection. Sci Amer 4: 56-65

ROTA, A, BALLARIN, C, VIGIER, B, COZZI, B, REY, R 2002: Age dependent changes in plasma anti-Mullerian hormone concentrations in the bovine male, female, and freemartin from birth to puberty: relationship between testosterone production and influence on sex differentiation. Gen Comp Endocrinol 129: 39-44

SATOH, S, HIRATA T, MIYAKE, Y, KANADA, Y 1997: The possibility of early estimation for fertility in bovine heterosexual twin females. J Vet Med Sci 59: 221-2.

SMITH, KC, PARKINSON, TJ, LONG, SE, BARR, FJ 2000: Anatomical, cytogenetic and behavioural studies of freemartin ewes. Vet Rec 146: 574-8

SMITH, KC, PARKINSON, TJ, PEARSON, GR, SYLVESTER, L, LONG, SE 2003: Morphological, histological and histochemical studies of the gonads of ovine freemartins. Vet Rec 152: 164-9

SZATKOWSKA, I, UDAŁA, J, CHOMICZEWSKA-MAZARAKI, A 1993: Przypadek leukocytarnego chimeryzmu komórkowego u niepłodnej maciorki rasy merynos polski. Med Weter 49: 565-567

SZATKOWSKA, I, UDAŁA, J, BARANOWSKI, P, KATKIEWICZ, M, STEPIEN, J 1998: Two cases of freemartinism in sheep. Acta Vet Brno 67: 189-192

SZATKOWSKA, I, UDAŁA, J, BŁASZCZYK, B, DĄBROWSKI, T, 2002: Cząstotliwość występowania chimeryzmu komórkowego u niepłodnych kóz rasy białej uszlachetnionej. Zesz Nauk PTZ 63: 209-215

YADAV, BR, SINGH, C, KUMAR, P, TOMER, OS, YADAV, JS 1993: Morphological, anatomical and cytogenetical investigations in sexually anomalous goats. Small Ruminant Res 11: 331-342

VIGIER, B, MAGRE, S, CHARPENTIER, G, BEZARD, J, JOSSO, N 1991: Anti-mullerian hormone and natural and experimental freemartin effect. Bull Assoc Anat (Nancy) 75: 29-32

ZHANG T, BUOEN LC, SEGUIN BE, RUTH GR, WEBER AF 1994 Diagnosis of freemartinism in cattle: the need for clinical and cytogenic evaluation. J Amer Vet Med Assoc 15: 1672-5 
Plate V

Szatkowska I. et al.: A study of three ... pp. 375-378

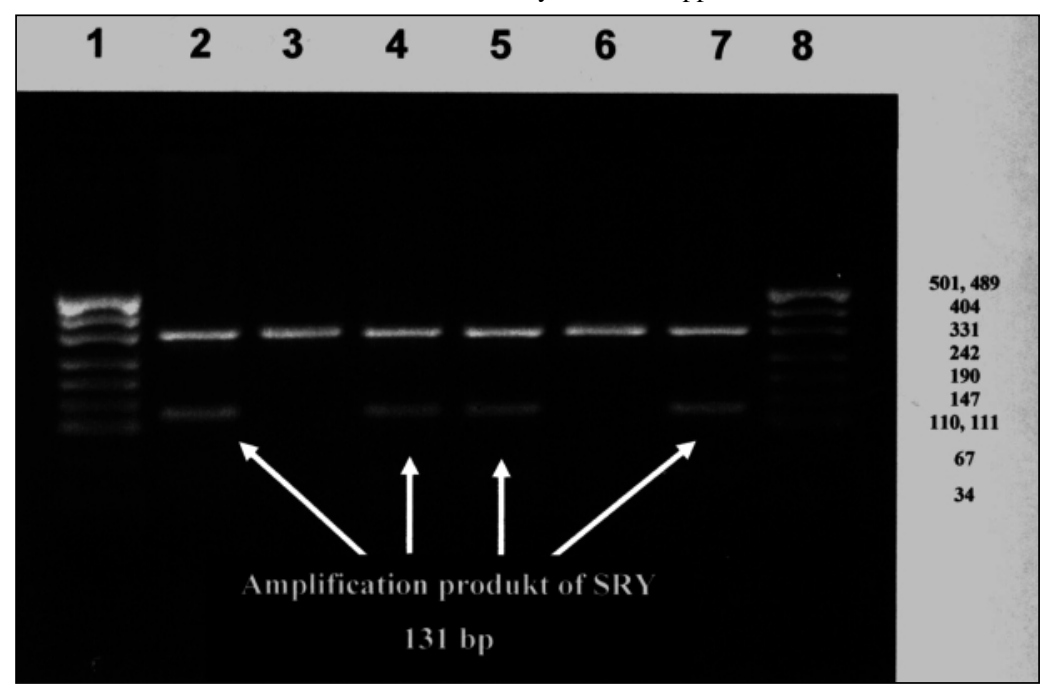

Fig. 1. PCR multiplex - amplification products of $G H(329 \mathrm{bp})$ and $S R Y$ ( $131 \mathrm{bp})$ genes; lanes 1 and 8 - DNA marker (pUC19/MspI); lane 2 - male (control sample), presence of $G H$ and $S R Y$ products; lanes 3 and 6 female (control sample), presence of $G H$ product, absence of $S R Y$; lanes 4, 5, and 7 - goats with chromosomal chimaerism, presence of $G H$ and $S R Y$ products

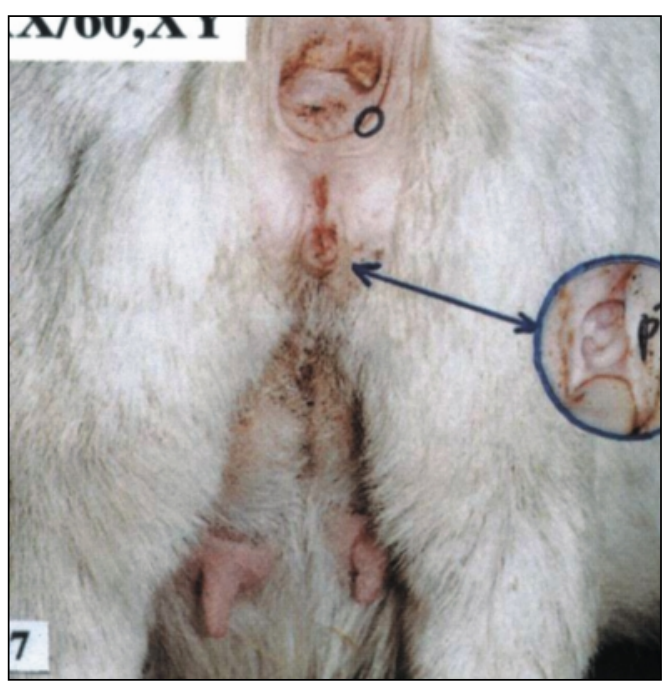

Fig. 2. External reproduction organs. Enlarged clitoris. Goat No. 8-B-97

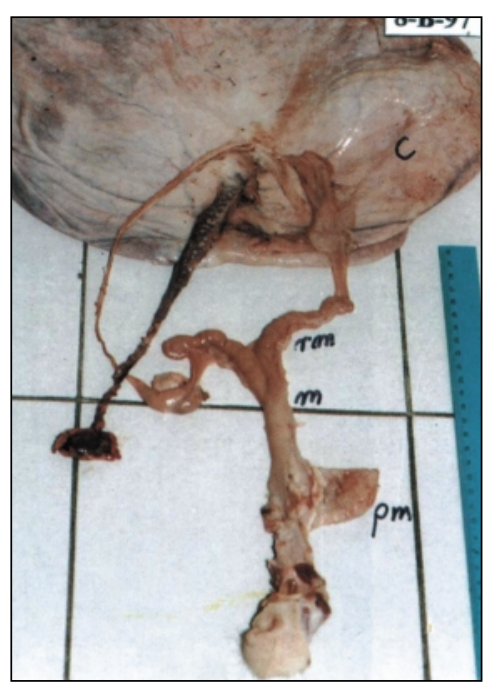

Fig. 3. Internal reproduction organs. Goat No. 8-B-97 
Plate VI
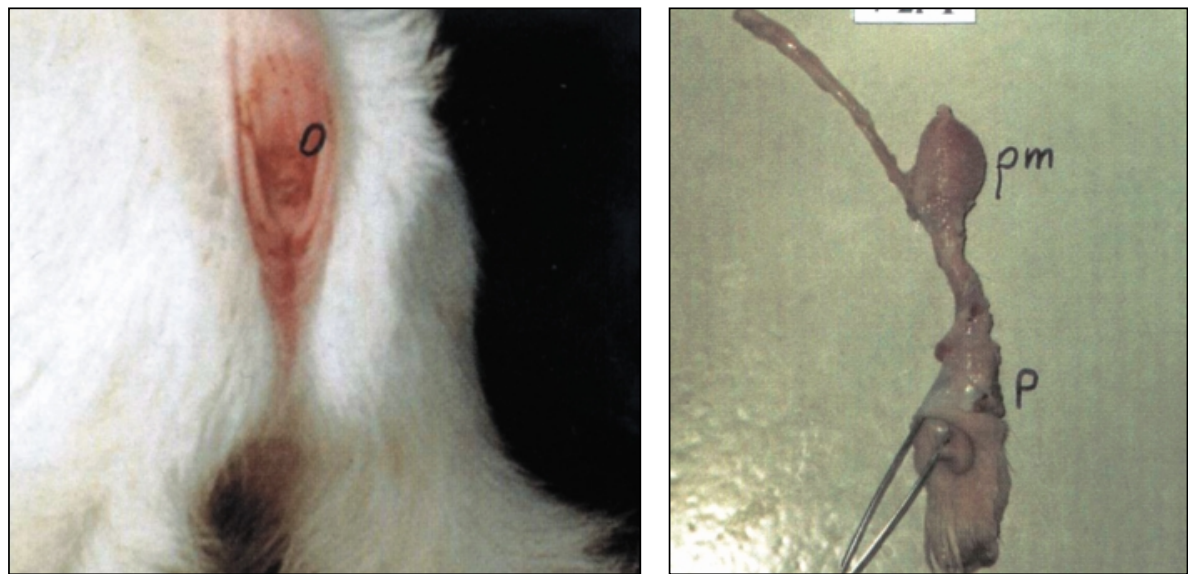

Fig. 4. External reproduction organs of goat No. 7-2r-F

Fig. 5. Internal reproduction organs of goat No. 7-2r-F 